\title{
THE DEVELOPMENT OF LEGAL REGULATION OF THE COMBATING CORRUPTION - MAIN CRITERIA FOR THE CONFIRMATION OF DEMOCRATIC VALUES IN THE EUROPEAN SOCIETY
}

\author{
Galina PISARSKA \\ "Neofit Rilsky" South-West University, Blagoevgrad, Bulgaria \\ galina_pisarska@abv.bg
}

\begin{abstract}
Corruption poses a serious danger to the democratic foundations of each country. The need of an effective legal mechanism for combating corruption is increasingly being interpreted as key criteria for strengthening democratic institutions and introducing modern standards of transparency and democratic control into the governance of society. There are adopted a number of national, regional and international legal anticorruption acts which are particularly important, especially in the context of Bulgaria's integration processes in the European area. In this connection, ensuring the democratic values in European society represents a big challenge for regulatory claims and capabilities of law with a view to the dynamic development of society. The current survey examines at the main type the development of anticorruption legal framework and aims to provide guidance for optimizing and improving the existing system of effective measures for the fighting against corruption and to clarify its place in the confirmation of democracy.
\end{abstract}

Keywords: corruption, anti-corruption legislation, democracy, values, European Union

\section{Introduction}

The dynamic development of European society and policies make citizens of European Union face serious challenges related to the understanding and practical realization of the values that underlie the functioning of the EU. The fundamental values [1] that inspire the Union to achieve its objectives are formulated both in primary law and in the case law of the Court of Justice of the EU and in political declarations of the European Council, which are subsequently formalized in the Treaties. The general provision of Article 2 the Treaty on European Union lists the values that, since the establishment of the first Community, have been values which are defended and asserted in the jurisprudence of the Court of Justice: respect for human dignity, freedom, democracy, equality, the rule of law, protection of human rights. These values are common to the Member States in a society characterized by pluralism, nondiscrimination, tolerance, fairness, solidarity and equality between women and men [2]. Title 2 of the TEU, which contains "provisions on democratic principles", put the principle on representative democracy in the foundation of functioning of the Union (Article $10 \S 1$ TEU), which refers to two elements: the direct representation of Union citizens in the European Parliament and the representation of the Member States in the European Council (through their governments) "who themselves are democratically accountable either to their national Parliaments, or to their citizens" (Article $10 \S 2$ TEU). In the last few years on international and national level, the 
confirmation of the values and principles of parliamentarism and democracy [3] has become a difficult activity especially in a country like the Republic of Bulgaria, where in the context of a still developing civil society, the rule of law and the market economy trends for the realization of social relations, which are traditionally marked as the manifestation of corrupt behaviour, have developed.

Corruption is a legal issue that has a key role for the proper functioning of the rule of law and ensuring good and honest governance. It interferes with the economic development of individual countries and the international community and threatens the stability of democratic institutions and the moral foundations of society. The participation of the people in the elaboration and making of political decisions forms the cornerstone of the claims of democratic legitimacy in the constitutional state [4]. Most modern constitutions have an explicitly expressed value orientation: they are built around one or another concept of the common good that ultimately reflects the objective value order. The common good, which includes a set of socially shared values, morally legitimizes both the political structure of constitutional democracy and the outcome of the political process formed by its legal and political institutions. In general, the values of the constitutional legal order, which form the core of the common good, predetermine the supreme goals of the state on the one hand, and on the other - specify in the rights and freedoms of the citizens [5]. Thus, through the acts of corruption in the public sector, one of the greatest dangers for any democratic state is emerging - values being thwarted and replaced by a sense of lack of democracy, social justice and law, and thus instilling to its citizens that the interests of one or another part of active citizenship are presented and imposed as goals of the entire nation.

Various concepts and characteristics have been used in theory and practice to describe the heterogeneous manifestations of corrupt behaviour. The international community is not yet committed to provide a single legal definition of the term of corruption, perhaps because it affects all areas of life and has various acts characterized with different degree of social danger. A comparative review of the essence of the phenomenon of "corruption" clearly shows that corruption is a complex, multi-layered social phenomenon that accompanies every society from the roots of its history, it is an antisocial phenomenon characterized by moral corruption of the personality and the social group, unlawful use of an official or other position to obtain an unlawful benefit [6]. It is generally considered as abuse of entrusted power for personal (private) gain [7] or a misuse of a certain position (and may be in the public life, in the judicial system, in a private company, even in a non-governmental organization) in order to obtain personal benefit [8]. In Bulgarian legislation, until recently, there was no single legal concept of corruption. However, through the provision of Art.3, para. 1 of the Act on combating corruption and the withdrawal of illegally acquired property came into force in January 2018, for the first time the Bulgarian legislator outlines the main features of the corruption act by giving a legal definition of the concept of corruption, namely corruption is present where, as a result of the occupied high public position, the person abuses his power, violates or fails to perform official duties in view to directly, or indirectly, gain unreasonable material or intangible benefits for themselves or for other persons. The main motive in performing a certain type of corruption behaviour related to the public service is to give preference to personal interest over the public interest. This understanding reinforces the belief that the circle of persons should be confined to occupation a particular state or public service or performing such a similar function.

One of the most striking effects of corrupt behaviour is precisely the impact on 
citizens' behaviour and the distortion of their minds, discouraging them from taking different initiatives, giving rise to mistrust and alienation by the institutions, and casting doubt on their ability to achieve a viable success. To overcome this unfavourable effect, a number of international and national measures have been taken to counter corruption practices. Particular attention should be paid to the legal framework of each country, as it is aimed at solving the main problem of power - raising citizens' confidence as a factor for the stability of the state democratic governance and realization of the perceived value system.

The need of development the measures for combating corruption has increasingly begun to be interpreted as a key criteria for strengthening democratic institutions and introducing modern standards of transparency and democratic control into society. Anticorruption legislation and practice are particularly important in the context of Bulgaria's integration processes in the European and Euro-Atlantic area. Reducing levels of corruption and efficiency in combating this phenomenon are becoming a key indicator of the country's progress in the pre-accession period. As the main priority of the state policy, which is recognized in the National Strategy for Prevention and Counteraction of Corruption adopted by the Council of Ministers in 2015-2020, is defined the fight against corruption. The main focus in this document is on shaping an effective system of anti-corruption bodies and laws, strengthening the capacity of institutions and improving inter-institutional interaction. In its attempt to become a full member of the European Union, Bulgaria should necessarily take into account the recommendations of the European Commission on the role of anti-corruption legislation and implement the necessary legislative measures in this direction. Only this way will help to promote and confirm democratic values in society and create an active civic and state position about intolerance towards corruption.

The current article will examine in a main way the development of the Bulgarian anticorruption law over the last 20 years, as the impact of the main international acts about the fight against corruption on the formation of the domestic legislation of the Republic of Bulgaria will also be taken into account.

\section{A brief review of the Anti-corruption legislation and policy in Bulgaria}

Over the last 20 years, the EU has seen the tendency to refine anti-corruption measures towards identifying separate systems of anti-corruption laws and bodies. Already in the second half of the 20th century, some EU member states understand that in the result of globalization of the economy, the scale of corruption and trade in influence is increasing, and increasingly modern and organized methods are emerging. Ordinary investigative and operational authorities are increasingly struggling to detect and counteract corruption, which consist of white collar crimes, financial and tax fraud, trade in influence, abuse of power, and so on. These crimes require a specialized approach and serious expert knowledge in various areas - finance, tax systems, corporate organization, and even macroeconomics and international law and trade. There is also a growing understanding that the big democratic reform in Eastern European states causes increasing the corruption behaviour in society. In the light of developing consensus in this area - reflected in a growing number of international and national documents adressing anti-corruption efforts - corruption has become a major concern within the whole European Union.

That is why most European states have started to reform their anti-corruption legislation and to create a separate system of anti-corruption bodies. One of these countries is also the Republic of Bulgaria. Its anti-corruption legislation is 
characterized by particular dynamism of development and efficiency in its application, which includes measures with an administrative and criminal nature.

Until 1997, the Bulgarian anti-corruption legal regulation was mainly expressed in the so-called "remedial/preventive measures", which mean that there is lack of concrete practical measures to prevent it. The main reason is that this period in the East European States is usually linked to the democratic reform and the process of transition from centralised systems, which have serious reflection on the governmental willingness to shape more effective institutional and policy tools with the potential to mitigate corruption. Corruption and anti-corruption policy have been major political issues since 1997, when a new Government came to power on a platform that included the fight against corruption as one of its main priorities. In addition, the membership of Bulgaria in the Council of Europe, as well as the start-up process of Bulgaria's accession to the EU, is accelerated through the process of adopting European legal mechanisms in the fight against corruption. The EU accession process has been one of the most important influences on the development of anticorruption policy, and anti-corruption is clearly recognized by the Government as a condition for both EU and NATO accession. Pressure from the European Commission was instrumental in encouraging the Government to produce the National Strategy, and anti-corruption policy has been an important part of the Accession Partnerships. The Commission has provided increasing assistance for the development of anti-corruption legislation.

Over the last 20 years, the Bulgarian government has adopted a number of strategic documents [9], which can be categorized in two groups:

- Strategic documents with a direct focus on the prevention, counteraction and fight against corruption: National AntiCorruption Strategy - 2001 and Program for its Implementation, Strategy for Transparent Governance, Prevention and Counteraction to Corruption 2006-2008, Integrated Prevention Strategy and Counteracting Corruption and Organized Crime 2009, The Strategy for Prevention and Counteraction to Corruption in the Judicial System - 2013, Methodology for Corruption Risk Assessment 2010-2014, Strategic Guidelines for Counteraction and Fight against Corruption 2015-2020, National Anti-Corruption Strategy 2015-2020.

- Strategic documents on different special sectors with indirect importance for the fight against corruption: National Strategy for Prevention and Control of Irregularities and Fraud Affecting the Financial Interests of the European Union, Updated Strategy for Continuing Judicial Reform, National Strategy for Development of the Public Sector in the area of public procurement, Common Government strategy, and the different sectoral strategies.

To fulfil the prescriptions of these documents, different actions have been taken by the authorities for creation legislative acts, whose main purpose is to achieve positive results in the fight against corruption and, above all, to meet society's expectations of democracy, fairness and transparency in the functioning of the state apparatus. The Bulgarian Parliament has adopted several normative acts with administrative nature, with the rank of a law: Law on the Forfeiture of Criminal Assets for the State, in force in 2005; Law on Prevention and Establishment of Conflict of Interest, into force in 2008, amended ten times; Law on the seizure of the property of illegally acquired property, into force in 2012; Law on the publicity of the property of persons holding higher state and others. However, the efforts taken against corruption by the Bulgarian institutions have been merely formalistic, and indeed the Union's own expectations about what the state have to do to meet the requirements of membership in combating corruption have often been limited to the 
ratification of conventions, without soliciting more meaningful change. The European Commission's assessments, given in its regular reports on Bulgaria's Process towards Accession and on Progress in Bulgaria under the Cooperation and Verification Mechanism [10], as well as the national assessments [11] continue to take into account a number of shortcomings in the legal framework that hinder progress in combating corrupt practices, and to seriously criticize the current documents by 2014 .

There are frequent changes in the legislative acts regulating the activities of the bodies for prevention, counteraction and fight against corruption, which is a prerequisite for the occurrence of differences in the concepts, lack or unbalanced horizontal and/or vertical relations and interaction between the authorities, and duplication/gaps in the regulation of the functions of the bodies for prevention and combat corruption. The legislative framework regarding corruption until 2018 is fragmented and encompasses various normative acts. It is characterized by the lack of a single legal anti-corruption act (law/code), which to define the concepts about the terms of "corruption", "corrupt behaviour", "corrupt action", anticorruption bodies, and to emphasize the regulated effective interaction between the institutions provided to deal with the prevention/fight and counteraction of corruption, as well as to uniform objective criteria for assessing the level of corruption both in the world and in Bulgaria. In this view, it could be concluded that the state of legal regulation until the adoption of the new anti-corruption law in 2018 does not guarantee compliance with the international requirements, enshrined in the Conventions that our country has ratified [12].

The European Commission's report to the European Parliament and the Council on Progress in Bulgaria under the Cooperation and Verification Mechanism 25 January 2017 [13] regarding the benchmark about the Efficient Anti-Corruption measures states that the development by the government of an updated national strategy for the fight against corruption has been an important step, but the challenge remains to ensure its implementation, to adopt the necessary legal framework and to set up the envisaged institutions. The Commission noted in its report as a recommendation that Bulgaria has to adopt a new legal framework on the fight against corruption in line with the intentions set out in the anticorruption strategy, to ensure its implementation, and to set up an effective anti-corruption authority.

In accordance with these recommendations the Government put in the governance priorities for the period 2017-2021 the adoption of a new anti-corruption law that will unify fragmented legislation and establish a single anti-corruption body based on the Commission for the seizure of illegally acquired property. In response to the need to create a more effective mechanism for counteracting organized crime and to outline the mechanisms for combating high-level corruption, in January 2018, Bulgaria adopted a comprehensive reform of its anti-corruption legislation - an Act on combating corruption and the withdrawal of illegally acquired property. The new law puts in place a comprehensive reform of the legislative framework for the prevention of conflicts of interest, illicit enrichment and corruption. With this act the Parliament aims to overcome the weaknesses resulting from the fragmented normative framework in the sphere of anti-corruption. Until its entry into force as stated, a piecemeal legislation exists in the legal order, including an Act on the Seizure of the State of Illegally Acquired Property, an Act on the Publicity of the Property of Persons Holding Higher State and Other Posts and the Act on the Prevention and Establishment of Conflict of Interests, the State Audit Office Act, the State Agency for National Security Act, which provide for the functioning of various bodies with 
anti-corruption functions (Commission for the Forfeiture of Unlawfully Acquired Property, Commission for the Prevention and Establishment of Conflict of Interests, Center for Prevention and Counteraction to Corruption and Organized Crime at the Council of Ministers, relevant units in the National Audit Office and State Agency for National Security). It establishes a new unified independent anti-corruption agency in charge of verifying conflicts of interest and private assets of high level officials, investigating allegations of malpractice among such officials, generally promoting the prevention of corruption, as well as conducting procedures for the seizing and confiscation of illicit assets. The new agency, named a Committee for Combating Corruption and the withdrawal of illegally acquired property, is based on a merger of a number of already existing institutions and is now fully operational.

On the basis of the latest Bulgarian anticorruption initiatives, the European Commission notes in its final report that Bulgaria has made significant progress on its recommendations regarding high-level corruption. However, the Bulgarian authorities will need to show concrete results and build a track record evidenced by final decisions in high level corruption cases. The new anti-corruption institutional framework requires continued monitoring in view of the need to consolidate the progress made. Undoubtedly, for the past 20 years, it could be said that Bulgaria has received such a flattering positive assessment of its fight against corruption for the first time.

The anti-corruption strategy for the period of 2015-2020, as well as the previous strategies, also emphasizes changes in criminal laws. The development of our criminal justice system in recent years has been linked to the efforts of the legislator to adapt our domestic law to the requirements of the European conventions and recommendations. These efforts at certain points are successful and in others less successful. The applied non-systematic approach over the years has led to the fact that at present, for some procedural institutes in Bulgaria, the standards of the Convention are far exceeded, and for another - at the border. Our criminal law has sufficient formations relevant to the use of the official position or the abuse of it in a personal interest. It focuses on those crimes that are most concerned with the public interest. At the same time, it is clear that the phenomenon of corruption is wider in its scope than the cases regulated in the Criminal Code and needs updating. But as this matter is too broad, it will not be discussed in this article.

\section{Conclusion}

The proper organization and purposeful implementation of measures to combat international and national corruption can only be effectively achieved if there is an appropriate institutional mechanism to rationalize the efforts of the international community and the national authorities. To this end, it is necessary to strengthen the national legally established norms and structures with competence in the fight against corruption. Corruption and anticorruption legislation has long been a declared priority for the Republic of Bulgaria. In this regard the Bulgarian institutions have taken serious initiatives and measures over the past 20 years to make significant progress in approximating national anti-corruption legislation to the requirements of international and European anti-corruption instruments. Although a number of important laws have been passed, some reforms have been ineffective, and the coordination of anti-corruption efforts has been poor until recently. Whether the development of anti-corruption legislation will prove effectiveness in increasing the trust of citizens in the institutions or will take a part in the system of repealed legislative acts that remain in the history of the anti-corruption policy of the country is yet to be understood. 
Nevertheless, the efforts of the Bulgarian authorities in this direction should be noticed, which in turn is a serious indicator for the promotion of democratic values in society.

\section{References}

[1] More detail about the theory of values and founding principles of European Union see Bogdandy A. and Bast J., Principles of European Constitutional Law, Oxford, Hart Publishing Ltd., 2010, p. 20-28

[2] Popova J., European Union Law, Sofia, Ciela, 2015, p. 31-33

[3] More detail about democracy as a form of governance see Drumeva E., Constitutional Law, Sofia, Ciela, 2018, p 88-91, 247-248; Bliznashki G., Parliamentary Law, Sofia, UPH “St. Kliment Ohridski”, 2015, p. 41-64; Barry B., Democracy, power and justice, Oxford, Clarendon Press, 1989;Arat Z.,Democracy and Human Rights in Developing Countries, London, Lynne Rienner Publishers, 1991, p.15-32,

[4] Bliznashki G., Common study about Constitution, Sofia, UPH "St. KlimentOhridski”, 2019, p. 255

[5] Bliznashki G., CommonstudyaboutConstitution, Sofia, UPH “St. KlimentOhridski”, 2019, p. 264-266

[6] Georgiev G. and Velinov L., Legal dictionary, Sofia, Urispress, 2007, p. 107

[7] Pope J., Confronting corruption: the Elements of a National Integrity System, The Source Book, Transparency International, 2000, p. 131

[8] Kamenova C., Corruption in the countries in develop, Corruption - legal instruments for combating, Sofia, Institute for legal sciences, 2003, p. 7

[9] Monitoring the EU Accession Process: Corruption and Anti-corruption Policy, Open Society Intitute/EU Accession Monitoring Program, 2002; Anticorruption policy of Bulgaria - review and recommendations, Sofia, Institute of market economy, 2016

[10] Commission of the European Union, 2018 Regular Report from the Commission to the European Parliament and the Council on Progress in Bulgaria undertheCooperationandVerificationMechanism, available on https://ec.europa.eu/info/policies/justice-and-fundamental-rights/effective-justice/rulelaw/assistance-bulgaria-and-romania-under-cvm/reports-progress-bulgaria-andromania en\#year2018

[11] Strategic guidelines for prevention and counteracting corruption for 2015-2020, 2015, available on the next link: http://rai-see.org/wpcontent/uploads/2015/08/STRATEGIC GUIDELINES FOR THE PREVENTION AND FIGHT AGAINST CORRUPTION 2015-2020.pdf; Report on Anti-corruption policy in Bulgaria, 2016r., Institute of market economy, available on the next link: https://ime.bg/var/images/Anticorruption_analysis_final.pdf

[12] The Criminal Law Convention on Corruption and the Additional Protocol to this Convention, the OECD Convention on combating bribery of foreign public officials in the framework of international business transactions, and the United Nations Convention against Corruption

[13] https://ec.europa.eu/info/files/progress-report-bulgaria-2017-com-2017-43 en 